\title{
PENGGUNAAN BEBERAPA PERANGKAP UNTUK MENGENDALIKAN HAMA PENGGEREK BATANG PADI PANDANWANGI (Oryza sativa var. Aromatic)
}

\author{
Disusun oleh : \\ Yuliani**) \\ Ai Resti Anggraeni*)
}

\begin{abstract}
Abstrak
Padi pandanwangi merupakan padi lokal Cianjur varietas jenis padi bulu (Javanica), padi ini tumbuh pada ketinggian 450-800 mdpl, umur tanaman mulai dari penanaman sampai panen mencapai 155 hari lebih lama daripada padi pada umumnya. Karena lamanya umur tanam padi Pandanwangi mengakibatkan populasi penggerek batang padi dapat berkembang dengan baik di areal penanaman tersebut dikareanakan ketersediaan makanannya selalu tersedia, untuk menekan populasi penggerek batang padi Pandanwangi dilakukan teknik penangkapan hama tersebut menggunakan perangkap lampu, perangkap feromon dan perangkap methyleugenol perangkap tersebut merupakan perangkap yang dapat memerangkap hama tanaman padi. Penelitian ini dilaksanakan di areal penanaman padi Pandanwangi milik Fakultas Sains Terapan Unsur pada bulan Maret-April, menggunaan Rancangan Acak Kelompok yang terdiri dari 4 perlakuan dan 3 kelompok dengan satu sampel dalam masing-masing kelompok, perangkap A (lampu), B (feromon), C (yellow sticy trap) dan D (methyleugenol). Hasil uji lanjut DMRT menunjukkan hasil yang paling tinggi pengaruhnya terhadap populasi penggerek batang padi Pandanwangi yang terperangkap adalah perangkap A (lampu) diteruskan dengan perangap B (feromon).
\end{abstract}

Kata kunci : Penggerek Batang Padi, Perangkap Lampu, Perangkap Feromon, Yellow Sticky Trap, Perangkap Methyleugenol.

\begin{abstract}
Pandanwangi rice is local Cianjur rice varieties of fur rice type (Javanica), this rice grows at an altitude of 450-800 masl, the age of plants from planting to harvest reaches 155 days longer than rice in general. Because the longevity of Pandanwangi rice causing a population of rice stem borer can develop well in the planting area cause of the food is always available, to suppress the population of Pandanwangi rice stem borer, the technique of catching these pests is using light traps, pheromone traps and methylengenol trap. The trap is a trap that can trap pests of rice plants. This research was conducted in Planting area of Pandanwangi rice owned by Applied Science Faculty of Suryakancana University in March until April, used random group planning that consist of 4 treatment and 3 groups with a sample in each group, $A$ trap (lamp), $B$ (pheromone), $C$ (yellow sticy trap) and D(methylengenol). Further test result DMRT reveals the highest influence toward rice stem borer population of Pandan wangi rice that trapped is A trap (lamp), forwarded by $B$ trap (pheromone).
\end{abstract}

Key words: Rice Stem Borer, light Trap, Pheromone Trap, Yellow Sticky Trap, Methyleugenol Trap.

*) Alumni Fakultas Sains Terapan UNSUR

**) Dosen Fakultas Sains Terapan UNSUR

$\begin{array}{lrr}\text { PENGGUNAAN } & \text { BEBERAPA } & \text { PERANGKAP } \\ \text { UNTUK MENGENDALIKAN } & \text { HAMA } \\ \text { PENGGEREK } & \text { BATANG } & \text { PADI } \\ \text { PANDANWANGI (Oryza sativa var. } \text { Aromatic) }\end{array}$




\section{PENDAHULUAN}

Padi Pandanwangi merupakan salah satu padi lokal Cianjur yang memiliki ciri khas yang mana padi ini memiliki aroma pandan dan tergolong pada jenis padi javanica (bulu). Pandanwangi memiliki umur yang panjang yaitu 155 hari, tinggi tanaman $168 \mathrm{~cm}$. Panjangnya umur tanam menjadi salahsatu fator yang mengakibatkan peluang besar untuk penggerek batang padi dapat terus berkembang dan mengakibatkan resiko gagal panen yang cukup besar.

Kehilangan hasil setiap tahun yang disebabkan oleh penggerek batang padi dapat mencapai 10-30\%, bahkan dapat menyebabkan tanaman padi menjadi puso (Idris, 2008 dalam Ratih, 2014). Selain dari pada itu intensitas serangan hama yang cukup tinggi, khususnya daerah Jawa Barat dan Jawa Tengah adalah hama penggerek batang padi. Serangan penggerek batang padi pada tahun 2012 terjadi di Jawa Barat tepatnya di daerah Karawang disebabkan oleh spesies penggerek batang padi kuning dengan serangan berkisar 15.000 ha (Baehaki, 2013).

Di Indonesia terdapat lima spesies penggerek batang padi yang menyerang tanaman baik itu di lahan irigasi ataupun lahan lebak dan pasang surut, adapun lima spesies tersebut adalah penggerek batang padi kuning (Scirpophaga incertulas), penggerek batang padi putih (Scirpophaga innotata), Chilo suppresalis, Chilo polychysus dan Sesamia infers (Baehaki, 2013).

Pengendalian penggerek batang padi disarankan mengikuti konsep pengendalian hama terpadu (PHT). Pengendalian hama tanaman secara terpadu (PHT) bertujuan untuk mengurangi bahkan meniadakan penggunaan pestisida sintetis. PHT merupakan konsep pengendalian hama dengan menggunakan lebih dari satu komponen pengendalian, dengan tujuan populasi hama selalu berada dalam kondisi yang tidak merugikan secara ekonomis, dan aman terhadap lingkungan. Di Indonesia pelaksanaan PHT didukung oleh UU No. 12 tahun 1992, tentang sistem budidaya tanaman PP No. 6 tahun 1995 tentang perlindungan tanaman (Laba, et al 2014).

Beberapa komponen PHT salahasatunya adalah pengendalian dengan bakar tanaman yang terkena penyakit, cabut tanaman yang terkena penyakit, gropyokan, perangkap lampu, perangkap feromon, perangkap perekat dan lain-lain (Laba, et al 2014). Perangkap lampu dengan beberapa unit alat pembunuh serangga, mampu menarik berbagai jenis serangga (nocturnal) yang tertarik pada cahaya lampu (Widaningsih, 2016), begitu pula dengan perangkap kuning berperekat dapat menarik serangga untuk datang. Ketertarikan serangga terhadap warna adalah salah satu cara adaptasi serangga di alam (Hakim et al, 2016).

Perangkap feromon (pheromone) adaSlah senyawa kimia yang digunakan untuk berkomunikasi oleh individu dalam satu spesies (Wilson, 1971 dalam Martono, 1997). Penggunaan perangkap feromon seks (sintetik) sangat efektif, efisien dan ramah lingkungan untuk mengendalikan hama penggerek batang padi, sebagai alat perangkap masal, maka penggunaan perangkap berferomon akan menurunkan tingkat populasi serangga jantan yang mana secara tidak langsung akan menekan jumlah serangga berkopulasi (kawin) sehingga akan menurunkan tingkat populasi serangga hama berikutnya (Samudra, 2011).

Penelitian penggunaan beberapa perangkap seperti perangkap lampu (light trap), sticky trap, Methylengenol (Petrogenol) dan perangkap ber-feromon untuk menangkap hama penggerek batang padi di areal penanaman padi pandanwangi belum pernah dilakukan, maka dianggap perlu adanya penelitian akan hal tersebut. 


\section{METODE PENELITIAN}

Penelitian ini dilakukan di areal pesawahan penanaman padi pandanwangi Fakultas Sains Terapan Universitas Suryakancana. Waktu pelaksanaan penelitian mulai dari bulan Maret sampai dengan bulan April 2019.

Keempat jenis perangkap yang berbeda yang mana masing masing perangkap telah dilakukan perancangan sedemikian rupa agar nantinya dapat diaplikasikan oleh petani dengan mudah, media dalam perangkap adalah air dicampur detergen. Masing-masing perangkap diletakkan di areal penanaman padi Pandanwangi berumur $7 \mathrm{mst}$. Perangkap dipasang di atas tanaman padi, dengan jarak antar perangkap dalam tiap ulangan adalah $8 \mathrm{~m}$.

Pengamatan dilakukan setiap satu minggu dua kali selama penelitian. Sampel diperoleh dengan cara mengambil hama yang terperangkap pada masing-masing perangkap yang ada pada tiga petak pengamatan kemudian diamati jenis spesies dan jumlah hama penggerek batang padi yang terperangkap.

Metode penelitian Penelitian ini menggunakan Rancangan Acak Kelompok (RAK) dengan empat perlakuan (jenis perangkap) dan 3 kelompok (petakan sawah), perangkap di beri media air detergen untuk semua perangkap kecuali sticky trap Adapun empat perangkap yang digunakan dalam penelitian tersebut adalah:
A. : Perangkap lampu (Light trap) yang sudah dirancang.
B. : Perangkap berisi Feromon sintetik (Fero-PBPK).
C. : Perangkap kuning berperekat (sticky trap).
D : Perangkap berisi Metyleugenol (Petrogenol).

Data yang diperoleh dilakukan tabulasi dan dihitung rata-rata populasi hama penggerek batang padi dengan menggunakan analisis kuantitatif sederhana (Supit, 2014) :

$$
\mu=\frac{\sum x i}{n}
$$

Keterangan :

$\mu$ : Rata-rata populasi penggerek

batang padi per lokasi.

$\mathrm{Xi}$ : Jumlah penggerek batang yang ditemukan per lokasi.

$\mathrm{n}$ : Banyaknya lokasi

Data yang diperoleh diolah menggunakan software Microsof Excell dan SPS, untuk melihat pengaruh dari beberapa jenis perangkap terhadap hama penggerek batang padi yang terperangkap. Selanjutnya dilakukan pengujian Hipotesis dengan uji Duncan Multiple Range Test (DMRT).

\section{HASIL DAN PEMBAHASAN}

Berdasarkan hasil penelitian yang telah dilakukan, untuk populasi hama penggerek batang padi yang terperangkap oleh ke empat perangkap yaitu perangkap lampu, perangkap feromon dan perangkap metyleugenol memiliki pengaruh yang signifikan terhadap hasil jumlah populasi penggerek batang padi yang terperangkap. Data tersebut dihasilakan berdasarkan uji ANOVA (Analisys of Variance) dengan membandingkan nilai P-Value dengan $\alpha$ 5\% (Lampiran) maka kesimpulannya tolak H0 dan terima H1: yaitu terdapat pengaruh jenis peranggkap terhadap jumlah populasi penggerek batang padi yang terperangkap. Dikarenakan adanya pengaruh maka dilakukan uji lanjut terhadap data tersebut menggunakan uji lanjut DMRT (Duncan Multiple Range Test) yang mana hasilnya ada di dalam table 1 . 
Tabel 1. Hasil uji DMRT pengaruh penggunaan perangkap terhadap populasi penggerek batang padi yang terperangkap dalam waktu 4 minggu.

\begin{tabular}{ccccc}
\hline \multirow{2}{*}{ Perlakuan } & \multicolumn{4}{c}{ Waktu Pengamatan (Minggu) } \\
\cline { 2 - 5 } & $\mathbf{1}$ & $\mathbf{2}$ & $\mathbf{3}$ & $\mathbf{4}$ \\
\hline $\mathrm{A}$ & $2.2 \mathrm{~b}$ & $6.0 \mathrm{~b}$ & $1.8 \mathrm{~b}$ & $2.0 \mathrm{c}$ \\
$\mathrm{B}$ & $1.3 \mathrm{~b}$ & $1.3 \mathrm{a}$ & $1.0 \mathrm{ab}$ & $1.0 \mathrm{~b}$ \\
$\mathrm{C}$ & $0.0 \mathrm{a}$ & $0.0 \mathrm{a}$ & $0.0 \mathrm{a}$ & $0.0 \mathrm{a}$ \\
$\mathrm{D}$ & $0.0 \mathrm{a}$ & $0.0 \mathrm{a}$ & $0.0 \mathrm{a}$ & $0.0 \mathrm{a}$ \\
\hline
\end{tabular}

Keterangan: Angka yang diikuti buruf yang sama menunjukan tidak ada beda nyata berdasarkan uji DMRT. Perlakuan A: Perangkap Lampu, B Perangkap Feromon, C Perangkap Yellow Sticky Trap dan D Perangkap Methyleugenol.

Hasil penelitaian pada tabel 1 . menunjukan perangkap A (perangkap lampu) merupakan jenis perangkap yang mampu memerangkap hama penggerek batang padi Pandanwangi dengan jumlah populasi paling banyak selama empat minggu waktu pengamatan. Pada waktu pengamatan minggu pertama, perlakuan $\mathrm{A}$ berbeda nyata dengan perlakuan perangkap C (methyleugenol) dan D (yellow stcky trap), akan tetapi tidak berbeda nyata dengan perangkap B (feromon).

Pada waktu pengamatan minggu kedua perangkap A (lampu) berbeda nyata dengan ketiga perlakuan perangkap lainnya. Pada waktu pengamatan minggu ke tiga, perangkap A (lampu) menunjukan hasil yang berbeda nyata dengan perlakuan C (yellow sticky trap) dan D (methyleugenol) akan tetapi tidak berbedanyata dengan perlakuan B (feromon) dapat dilihat pula bahwa pada minggu ke tiga perlakuan B (feromon), C (yellow sticky trap) dan D (methyileugenol) menunjukan hasil yang tidak berbeda nyata. Pada waktu pengamatan minggu terahir (minggu ke empat) perlakuan A (lampu) menunjukan hasil yang berbedanyata dengan tiga perlakuan lainnya, dan perlakuan B (feromon) yang berbeda nyata dengan perlakuan perlakuan A (lampu), C (yellow sticky trap) dan D (methyleugenol) perlakuan A (lampu) merupakan perlakuan yang memberikan hasil paling baik terhadap jumlah populasi hama penggerek batang padi Pandanwangi, hal ini sesuai dengan pernyataan Baehaki (2013) bahwa populasi penggerek batang padi yang terperangkap paling banyak terdapat pada perangkap lampu, pada perangkap lampu hama yang terperangkap bukan hanya hama jantan melainkan keduanya (jantan dan betina) (Gambar 4.1) pernyataan tersebut sesuai dengan pakta dilapangan yang menunjukan hama yang terperangkap ada hama jantan dan betina yang diperkuat hasil survey mengenai ilmu hewan oleh (Arora, 2000), selain daripada itu penggerek batang padi pada umumnya tertarik pada lampu pada malam hari karena dia merupakan hama nokturnal (Hendarsih dan Usyati, 1999). Perangkap lampu umumnya sangat efisien digunakan untuk menangkap serangga terbang malam khususnya golongan famili Lepidoptera (Pertiwi et al ., 2013). $\begin{array}{lrr}\text { PENGGUNAAN BEBERAPA } & \text { PERANGKAP } \\ \text { UNTUK MENGENDALIKAN } & \text { HAMA } \\ \text { PENGGEREK } & \text { BATANG } & \text { PADI } \\ \text { PANDANWANGI (Oryza sativa var. } & \text { Aromatic) }\end{array}$
YULIANI

AI RESTI ANGGRAENI 


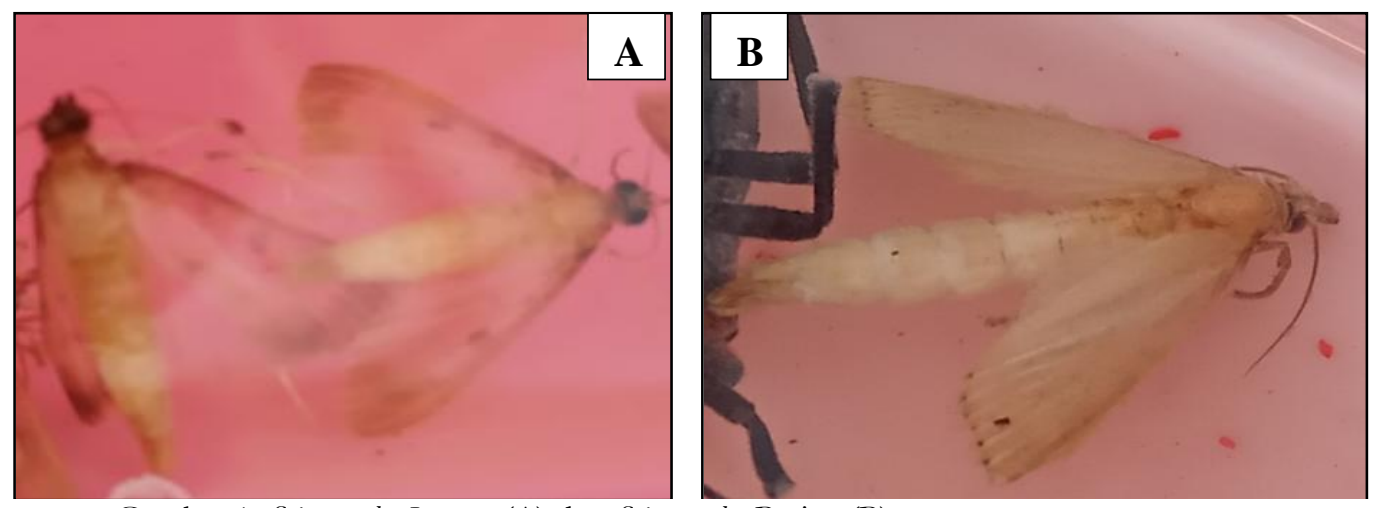

Gambar 1. S.incertulas Jantan (A) dan S.incertula Betina (B).

Perbedaan penggerek batang padi jantan dan betina dapat dilitah pada gambar 1. yang mana S.incertula jantan (A) memiliki ciri yang berbeda dengan penggerek batang padi betina, pada penggerek batang padi jantan (A) titik hitam sayap dari penggerek batang padi jantan tidak terlalu terlihat (lebh samar) serta terdapat 4 bintik hitam di ujung sayapnya, panjang sayap penggerek batang padi jantan lebih pendek dan abdomen penggerek batang padi jantan lebih mengkerucut. Sedangkan penggerek batang padi betina (B) memiliki sayap yang lebih panjang, abdomennya lebar dan binti hitam di tengahnya lebih jelas. Dapat dilihat pada gambar 4.2 yang menunjukkan perbedaan penggerek batang padi jantan dan betina lebih jelas

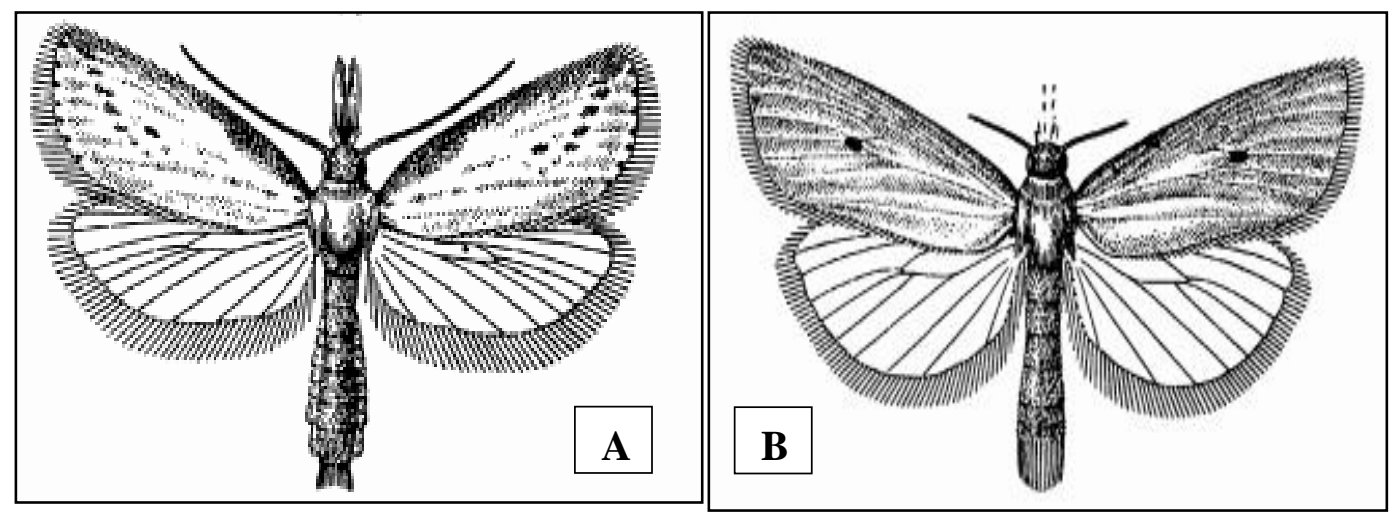

.Gambar 2. Penggerek Batang Padi S.incertula Dewasa Betina (A) dan S.incertula jantan (B) (Arora,

Hasil penelitian di lapangan selain hama penggerek batang padi yang terperangkap oleh perangkap lampu banyak pula hama lain yang terperangkap seperti Walang sangit (Leptocorica acuta), Kepik hijau (Nezara viridula), Belalang (Caelifera), Laron dan nyamuk. Berdasarkan hasil tersebut sejalan dengan penelitian yang dilakukan oleh Ilham et al,, (2018) yang menyatakan secara alami hama serangga mudah tertarik dengan cahaya. Hama serangga yang tertangkap pada saat pegujian alat dalam 2000).

penelitiannya adalah walang sangit (Leptocorica acuta), kepinding tanah (Scotinophora coarctata), kepik hijau (Nezara viridula), penggerek batang padi putih (Scripophaga innotata) dan belalang (Caelifera).

Hasil penelitain pada tabel 1 . menunjukkan perlakuan perangkap B (feromon) menunjukkan jumlah populasi penggerek batang padi pandanwangi yang lebih baik dibandingkan perangkap C (yellow stcy trap) dan D (methyleugenol), tetapi tidak lebih baik dibandingkan

\section{PENGGUNAAN BEBERAPA PERANGKAP UNTUK MENGENDALIKAN HAMA PENGGEREK BATANG PADI \\ PANDANWANGI (Oryza sativa var. Aromatic)}

YULIANI

AI RESTI ANGGRAENI 
perlakuan perangkap A (lampu). Hal ini disebabkan perangkap feromon adalah perangkap yang digunakan untuk merangkap penggerek batang padi dengan menggunakan feromon yang mana perangkap feromon dapat digunakan sebagai penarik seks (sex attractant) serangga jantan, sehingga serangga jantan akan terjebak dan dapat dimatikan (Budimarwati, 1997). Feromon yang digunakan adalah feromon (Fero PBPK (Scirpophaga incertulas Walk)) yang diperoleh dari BB BIOGEN yang mana feromon tersebut diketahui mengandung senyawa aktif Z-11-Hexadecelal (Komponen utama) dan Z-9-Hexadecenal (komponen minor) yang diserapkan pada karet septa. selain daripada penggerek batang padi dari spesies warna kuning ada juga spesies lain yang terperangkap yaitu belalang dan hama walang sangit yang terperangkap pada perangkap feromon.

Pada tabel 1. selama waktu pngamatan 4 minggu perangkap C (yellow sticky trap) dan D (metyleugenol) menunjukan tidak adanya jumlah populasi hama penggerek batang padi pandanwangi yang terperangkap, yang mana pada perangkap metyleugenol tidak terdapat hama penggerek batang melainkan hanya ada hama lalat buah (Bactrocera sp), hasil ini menunjukkan pernyataan (Towaha, 2012) bahwa senyawa metyleugenol merupakan turunan dari eugenol yang dapat digunakan sebagai antraktan untuk menarik lalat buah jantan.
Perangkap yellow sticky tidak terdapat hama penggerek batang padi Pandanwangi dan selain daripada itu karena penempatan perangkap yang berada $5 \mathrm{~cm}$ diatas permukaan tanaman padi pandanwangi yang memiliki tinggi lebih dari tinggi tanaman padi pada umumnya yaitu $168 \mathrm{~cm}$ (MP3C, 2015), sedangkan penggerek batang padi pada saat pagi dan siang hari pada umumnya bersembunyi pada bagian pangkal batang padi atau pada bagian bawah helai daun (Sutiharni dan Pattiasina, 2017), hal tersebut dipengaruhi oleh jam biologis serangga yang memungkinkan waktu yang tepat untuk serangga istirahat dan kapan waktu beraktivitas (Elzinga, 1997 dalam Yunus, 2011), sehingga hasil penelitian dilapangan hama yang terperangkap pada perlakuan C (yellow sticy trap) bukan hama penggerek batang padi melainkan lalat buah (Bactrosera sp), wereng, belalang, walang sangit (Leptocorica acuta) dan nyamuk. Berdasarkan hasil penelitian yang telah dilakukan di areal penanaman padi Pandanwangi terdapat dua spesies penggerek batang padi yang terperangkap oleh ke empat perangkap yang dipasang, kedua spesies tersebut adalah spesies penggerek batang padi kuning dan penggerek batang padi merah jambu (Gambar 4.3), untuk spesies penggerek batang padi kuning ini merupakan spesies yang dominan terdapat di Indonesia (Mulyaningsih et al., 2009).
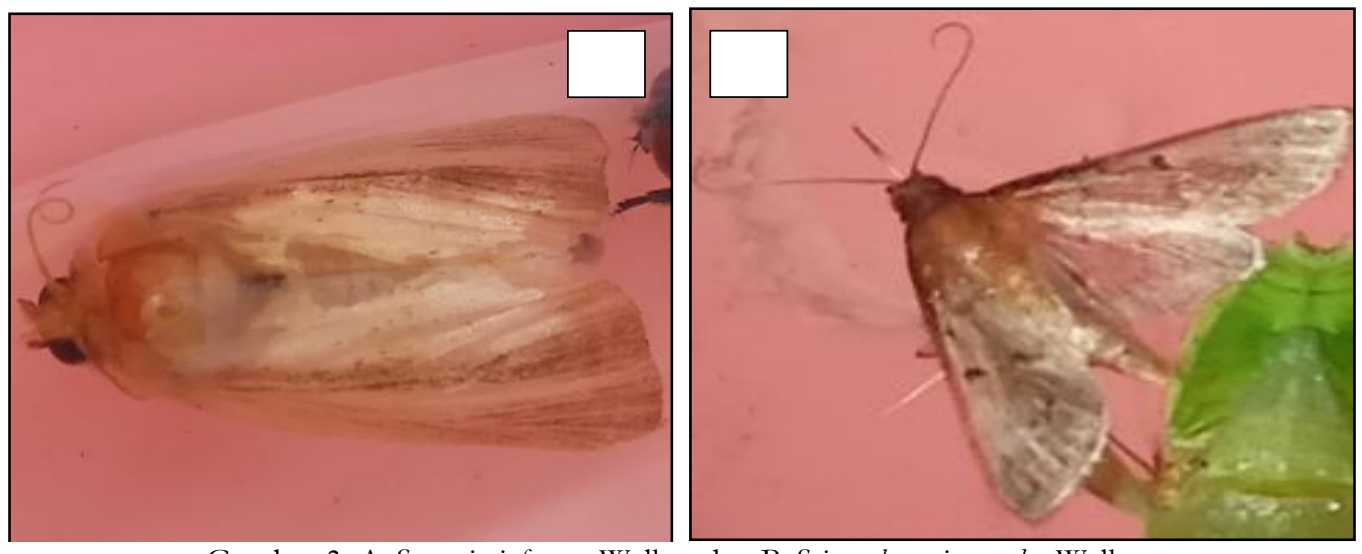

Gambar 3. A Sesamia inference Walker dan B Scirpophaga incertulas Walker.

\section{PENGGUNAAN BEBERAPA PERANGKAP UNTUK MENGENDALIKAN HAMA PENGGEREK BATANG PADI \\ PANDANWANGI (Oryza sativa var. Aromatic)}

YULIANI

AI RESTI ANGGRAENI 
Berdasarkan gambar 3. dapat dilihat perbedaan dari kedua spesies yang terperangkap, Sesamia inference Walker (A) merupakan hama penggerek batang padi merah jambu yang mana dia memiliki sayap depan berwarna coklat terang dan sayap belakang berwarna keputih putihan, bagian sayap penggerek batang padi merah jambu lebih kekar dan terdapat corak coklat gelap pada bagian tengah sayap yang terpusat dari sayap depan menuju ujung sayap. Sedangkan Scirpophaga incertulas Walker (B) memiliki sayap berwarna coklat kekuning-kuningan, terdapat bintik hitam yang jelas di bagian tengan sayap depan, dan memilkiki vensi sayap seperti gambar 4 .

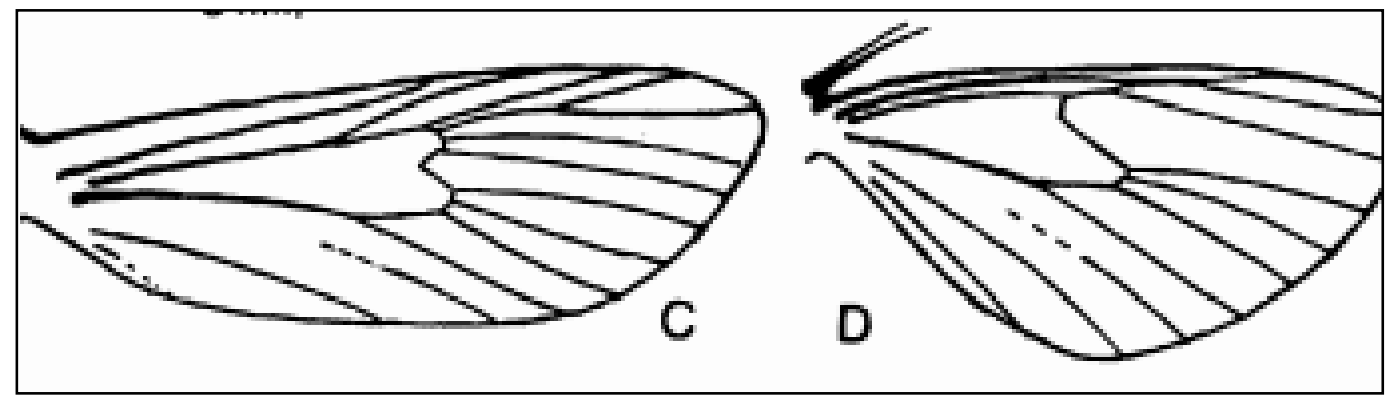

Gambar 4. venasi sayap depan (C) dan sayap belakang (D) (Arora, 2000).

Banyaknya spesies penggerek batang padi kuning diduga budidaya yang dilakukan di areal penanaman tersebut tidak adanya pergiliran tanaman sehingga populasi penggerek batang padi $S$. incertulas lebih dominan, hal tersebut sesuai pernyataan Hendarsih dan Usyati (2009) dalam Aryantini et al., (2015) yang meyatakan penanaman padi secara terus menerus sepanjang tahun berakibat poplasi penggerek batang padi S. incertulas terus berkembang. Banyaknya penggerek batang padi kuning di areal pandanwangi diperkuat dengan data penelitian yang telah dilakukan oleh Ariyantini et al.,(2015) yang menunjukkan perbedaan jumlah masing-masing jenis spesies penggerek batang padi yang ditemukan di setiap ketinggian tempat, yang mana penggerek batang padi kuning $S$. incertulas ditemukan di ketinggian 250-500 mdpl paling dominan didapatkan sedangkan S. inferens diketinggian 250-500 lebih sedikit ditemukan, namun kedua spesies tersebut lebih dominan di bandingkan dengan spesies lainya (Tabel 4.3), sedangkan areal tempat penelitian dilakukan berada di ketinggian 436-675 mdpl (MP3C, 2015) maka tidak heran ketika hasil penelitian ini hanya terdapat dua spesies yaitu $S$. incertulas dan S. Inferens.

Faktor lain yang mempengaruhi yaitu sistem penanaman yang mana tempat penelitan yang dilakukan adalah lahan yang telah mendapatkan sertifikasi organik maka sistem penanaman di areal sawah tersebut selalu dilakukan secara organik, hal tersebut berpegaruh terhadap spesies penggerek batang padi yang diperoleh di areal penelitian, pernyataan tersebut diperkuat oleh penelitian yang telah dilakukan oleh Hadi et al.,(2015) untuk melihat populasi penggerek batang padi di areal penanaman sawah organik dan anorganik dan hasilnya menunjukkan peresentase kehadiran S.incertulas dan $S$. inferens sedikit lebih banyak dijumpai di ekosistem sawah organik. Presentase data yang diperoleh $62 \%$ penggerek batang padi S.incertulas lebih memilih sawah organik dan 38\% sawah anorganik. Sedangkan untuk spesies S. inferens 56\% lebih memilih sawah organik dan 44\% lainnya memilih sawah anorganik (Hadi et al., 2015). $\begin{array}{lrr}\text { PENGGUNAAN BEBERAPA } & \text { PERANGKAP } \\ \text { UNTUK MENGENDALIKAN } & \text { HAMA } \\ \text { PENGGEREK } & \text { BATANG } & \text { PADI } \\ \text { PANDANWANGI (Oryza sativa var. } & \text { Aromatic) }\end{array}$
YULIANI

AI RESTI ANGGRAENI 
Tabel 2. Hasil Uji Lanjutan DMRT Pengaruh Perangkap Terhadap Spesies Penggerek Batang Padi Kuning (Scirpophaga incertulas Walker).

\begin{tabular}{cc}
\hline Perlakuan & Banyaknya Spesies Penggerek Batang Padi Kuning \\
\hline A & $13.8 \mathrm{~b}$ \\
B & $4.2 \mathrm{a}$ \\
C & $0.0 \mathrm{a}$ \\
D & $0.0 \mathrm{a}$
\end{tabular}

Keterangan: Angka yang diikuti buruf yang sama menunjukan tidak ada beda nyata berdasarkan uji DMRT. Perlakuan A: Perangkap Lampu, B Perangkap Feromon, C Perangkap Yellow Sticy Trap dan D Perangkap Methyleugenol.

Berdasarkan tabel 2. dari jenis perangkap yang digunakan memiliki pengaruh terhadap banyaknya spesies hama penggerek batang padi kuning S.interculas menunjukan pelakuan perangkap A (lampu) merupakan perlakuan yang memiliki pengaruh paling baik, hal ini terlihat pada tabel 4.2 perlakuan perangkap A (lampu) berbeda nyata dengan ketiga perlakuan lainnya yaitu perlakuan B (feromon), C (yellow sticky trap) dan D (methyleugenol). Data juga menunjukan hasil dari ketiga perlakuan B (feromon), C (yellow sticky trap) dan $\mathrm{D}$ (methyleugenol) yang tidak berbeda nyata.

Berdasarkan hasil penelitian perlakuan A (lampu) dengan hasil ratarata banyaknya spesies penggerek batang padi kuning S.interculas sebanyak 13,8 ekor dan perlakuan B (feromon) sebanyak 4,2 ekor. Perlakuan lampu dan feromon mampu memerangkap spesies penggerek batang padi kuning lebih banyak diabndingkan perangak $\mathrm{C}$ (yellow sticky trap) dan D (methyleugenol), hal ini dipengaruhi oleh aktifitas serangga yang mengikuti jam biologisnya yang mana hama penggerek batang padi S.incertilas yang merupakan hewan nocturnal, sehingga aktivitas kemunculan, aktivitas terbang, maupun peletakan telur terjadi pada malam hari (Yunus et al., 2011). Aktivitas terbang S.incertulas berlangsung sejak pukul 18.00 s.d 01.00 dinihari, setelah pukul 01.00 tidak dijumpai ngengat penggerak batang datang, demikian pula pada siang hari tidak dijumpai ngengat terbang kecuali ada sesuatu yang mengganggu ngengat maka dia akan terbang namun terbangnya pun hanya jarak dekat dan tidak teratur arahnya. Pada saat $S$. incertulas aktif terbang dia tertarik pada cahaya lampu terutama ultraviolet (Pathak dan Khan, 1994 dalam Yunus et al., 2011).

\section{KESIMPULAN}

Penggunaan beberapa perangkap berpengaruh terhadap populasi penggerek batang padi yang terperangkap yang mana perangkap yang paling banyak memerangkap penggerek batang padi adalah perangkap lampu dan di teruskan oleh perangkap feromon, sedangkan untuk perangkap lain seperti perangkap methyleugenol dan yellow sticky trap kurang tepat untuk memerangkap hama penggerek batang padi. Sedangkan perangkap yang berpengaruh terhadap spesies penggerek batang padi hanya berpengaruh terhadap spesies penggerek batang padi kuning S.incertulas, selain daripada penggerek batang padi kuning yang terperangkap ada pula hama penggerek batang padi merah jambu S.inferes yang terperangkap, namun untuk spesies ini tidak ada pengaruh perhadap penggunaan perangkap yang digunakan kerena hanya ada sedikit populasinya. 


\section{DAFTAR PUSTAKA}

Arora, G, S. 2000. Record Of The Zoological Survey Of India. Occasional. June, No 181, hal1-169. Delhi.

Aryantini, L., Supartha, W,I dan Wijaya, N, I. 2015. Kelimpahan Populasi dan Serangan Penggerek Batang Padi pada Tanaman Padi di Kabupaten Tabanan. E-Jurnal Agroteknologi Tropika 4(3):203-212. Fakultas Pertanian Universitas Udayana.

Baehaki, S.E. 2013. Hama penggerek batang padi dan teknologi pengendalian. Iptek Tanaman Pangan. 8(1):1-14.Balai Besar Penelitian Tanaman Padi.

Budimarwanti, C. 1997. Feromon dan Metileugenol, Pengendali Hama Tampa Merusak Lingkungan. Cakrawala Pendidika. (1):141-149.

Hadi, M., Soesilohadi, H, RC., Wagiman, dan Suharjono, R, Y. 2015. Populasi Penggerek Batang Padi pada Ekosistem Sawah Organik dan Sawah Anorganik. Jurnal BIOMA. 17(2):106-117.

Hakim, L., Surya, E dan Muis, A. 2016. Pengendalian Alternatif Hama Serangga Sayuran dengan Menggunakan Perangkap Kertas. Jurnal Agro. 3(2):21-33. Universitas Serambi Mekkah. Banda Aceh.

Hendarsih, S., dan Usyati, N. 1999. Perangkap Feromon Seks untuk Penggerek Batang Padi Kuning Scirpophaga incertulas. Jurnal Perlindungan Tanaman Indonesia. 5(2), 77-82.

Ilham, A, H., Syahta, R., Anggara, F dan Jamaluddin. 2018. Alat Perangkap Hama Serangga Padi Sawah Menggunakan Cahaya dari Tenaga Surya. Journal of Applied Agricultural Science and Tecbnolog. 2(1): 11-19. Program Studi Mesin dan Peralatan Pertanian.
Politeknik Pertanian Negeri Payakumbuh.

Laba, W,I., Wahyuno, D dan Rizal,M. 2014. Peran PHT, Pertanian Organik dan Biopestisida Menuju Pertanian Berwawasan Lingkungan dan Berkelanjutan. Prosiding Seminar Nasional Pertanian Organik. 25-34. Balai Penelitian Tanaman Rempah dan Obat. Jalan Tentara Pelajar No. 3 Bogor.

Martono, E. 1997. Pengaruh Dan Pemanfaatan Feromon Seks Terhadap Serangga Hama. Jurnal Perlindungan Tanaman Indonesia. 3(2):106-114. Fakultas Pertanian Universitas Gajah Mada.

Masyarakat Pelestari Padi Pandanwangi Cianjur (MP3C). 2015. Buku Persyaratan Permohonan Pendaftaran Indikasi Geografis Beras Pandanwangi Cianjur. Cianjur (ID).

Mulyaningsih, Enung S., D. Puspita, dan L. Salmet. 2009. Dampak Padi Transgenik Mengekspresikan Gen cry IA(b) untuk Ketahanan terhadap Penggerek Batang Padi di Lapang Terbatas terhadap Serangga Bukan Sasaran. Jurnal HPT Tropika. 9(2): 85- 91.

Pertiwi, N, E., Mudjiono, G dan Rachmawati, R. 2013. Hubungan Populasi Ngengat Penggerek Batang Padi yang Tertangkap Perangkap Lampu dengan Intensitas Serangan Penggerek Batang Padi di Sekitarnya. Jurnal Hama Penyakit Tanaman. 1(2):8895. Universitas Brawijaya Jln. Veteran, Malang.

Ratih, I. S., Karindah, S dan Mudjiono, G. 2014. Pengaruh Sistem Pengendalian Hama Terpadu Dan Konvensional Terhadap Intensitas Serangan Penggerek Batang Padi dan Musuh Alami Pada Tanaman Padi. Jurnal HPT. 2 (3):18-27. Universitas Brawijaya. Malang. $\begin{array}{lrr}\text { PENGGUNAAN } & \text { BEBERAPA } & \text { PERANGKAP } \\ \text { UNTUK MENGENDALIKAN } & \text { HAMA } \\ \text { PENGGEREK } & \text { BATANG } & \text { PADI } \\ \text { PANDANWANGI (Oryza sativa var. } \text { Aromatic) }\end{array}$
YULIANI

AI RESTI ANGGRAENI 
Samudra, M., I. 2011. Perangkap Berferomon Pengendalian Penggerek Batang Padi Kuning. Jurnal Agroinovasi.33(87): 13-14.

Supit, M. M., Tarore, D., Mamahit, J. M., dan Kaligis, J. B. 2014. Penggunaan Beberapa Jenis Perangkap Dengan Feromon Terhadap Kumbang Kelapa (Oryctes Rbinoceros L.) (Coleoptera: Scarabaeidae). Jurnal 5(2). Universitas Unsrat Manado.

Sutiharni dan Pattiasina, W,J. 2017. Kajian Keberadaan Laba-Laba dan Tumbuhan pada Lahan Padi Sawah dalam Mengendalikan Hama Penggerek Batang Padi. Jurnal Agrotek. 5(6):1-11. Fakultas Pertanian UNIPA. Jl Gunung Salju Papua Barat.

Widaningsih , D. 2016. Kajian Bioekologi Hama-Hama Penting Beras dan Upaya Pengendaliannya. Skripsi. Fakultas Pertanian. Universitas Udayana. Denpasar.

Yunus, M., Martono, E., Wijonarko, A dan Soesilohadi, H,RC. 2011. Aktivitas Ngengat Schirpophaga incertulas di Wilayah Kabupaten Klaten. Jurnal Perlindungan Tanaman Indonesia. 17 (1):18-25. 